One patient had severe shock due to $60 \%$ burns but was not uraemic. The patients of Schumer and Nyhus (1970) with oligaemic shock had high serum phosphorus levels (actual values not stated) which rapidly returned to normal when they were given corticosteroids.

\section{Conclusion}

This study shows that the causes of both an increase and a decrease in the serum phosphorus concentration are varied. The main clinical importance of this estimation at the present time is still in the diagnosis of hyperparathyroidism and hypoparathyroidism. However, the clinician must be aware of the other factors which affect the serum phosphorus level. In many cases there is no explanation for the change, and further work needs to be done in order to determine the effects of various diseases and drugs on phosphorus metabolism.

Requests for reprints should be sent to Dr. M. G. Betro, Institute of Medical and Veterinary Science, P.O. Box 14, Rundle Street, Adelaide, S.A., 5000, Australia.

\section{References}

Amutzio, D. S., Stutzman, F., Shrifter, N., and Nesbitt, S. (1952). Fournal of Laboratory and Clinical Medicine, 39, 26

Anderson, D. C., Peters, T. J., and Stewart, W. K. (1969). British Medical fournal, 4, 402.

Annino, J. S., and Relman, A. S. (1959). American fournal of Clinical Pathology, 31, 155 .

Bunker, J. P. (1966). Anesthesiology, 27, 446.

Carruthers, B. M., Copp, D. H., and McIntosh, H. W. (1964). Fournal of Laboratory and Clinical Medicine, 63, 959

Christian, D. G. (1970). American fournal of Clinical Pathology, 54, 118.

Condon, J. R., and Nassim, R. (1970). British Medical fournal, 1, 110.

Cook, P. B., Nassim, J. R., and Collins, J. (1959).Quarterly fournal of Medicine, 28, 505

Duarte, C. G. (1968). Metabolism: Clinical and Experimental, 17, 420.

Duarte, C. G., and Bland, J. H. (1965). Metabolism: Clinical and Experimental, 14, 211.

Fauley, G. B., Freeman, S., Ivy, A. C., Atkinson, A. J., and Wigodsky, H. S. (1941). Archives of Internal Medicine, 67, 563.
Fourman, P., and Royer, P. (1968). Calcium Metabolism and the Bone, 2nd edn. Oxford, Blackwell Scientific.

Frank, B. W., and Kern, E. (1962). Archives of Internal Medicine, 110, 865.

Fraser, F., and MacIntyre, I. (1970). In Biochemical Disorders in Human Disease, ed. R. H. S. Thompson and I. D. P. Wootton, 3rd edn. London, Churchill.

Friis, T. (1961). Danish Medical Bulletin, 8, 72.

George, W. K., et al. (1964). New England fournal of Medicine, 270, 726

Gilbert, F. E., Casey, A. E., Downey, E. L., Thomason, S., and Deacy, J. V. (1970). Alabama fournal of Medical Sciences, 7, 343 .

Gonzalez, C. F., Finberg, L., and Bluestein, D. D. (1964). American fournal of Diseases of Children, 107, 476

Goodman, L. S., and Gilman, A. (1965). The Pharmacological Basis of Therapeutics, 3rd edn. New York, Macmillan.

Greenberg, B. G., Winters, R. W., and Graham, J. B. (1960). Fournal of Clinical Endocrinology and Metabolism, 20, 364.

Henry, J. B. (1969). In Clinical Diagnosis by Laboratory Methods, ed. I Davidsohn and J. B. Henry. 14th edn. Philadelphia, Saunders. Henry, R. J. (1964). Clinical Chemistry, Principles and Technics. New York,

Hoffman, W. S. (1970). The Biochemistry of Clinical Medicine, 4th edn. Chicago, Year Book Medical Publishers.

Jordon, G. W. (1966). American Fournal of Medicine, 41, 381.

Kupfer, S., and Kosovsky, J. D. (1965). Fournal of Clinical Investigation, 44, 1132.

Lafferty, F. W., Spencer, G. E., and Pearson, O. H. (1964). American fournal of Medicine, 36, 514

Lehr, D., Krukowski, M., and Colon, R. (1966). Fournal of the American Medical Association, 197, 105.

Lancet, 1970, 1, 820.

McGeown, M. G., Martin, E., and Neill, D. W. (1955). Fournal of Clinical Pathology, 8, 247.

Mather, A., and Mackie, N. R. (1960). Clinical Chemistry, 6, 223.

Miller, M., Drucker, W. R., Owens, J. E., Craig, J. W., and Woodward, H. (1952). Fournal of Clinical Investigation, 31, 115

Mostellar, M. E., and Tuttle, E. P. (1964). Fournal of Clinical Investigation, 43, 138.

Okel, B. B., and Hurst, J. W. (1961). Archives of Internal Medicine, 108, 157.

Oliveira, H. L. de, and Laus-Filho, J. A. (1961). Lancet, 2, 215.

Parfitt, A. M. (1965). Fournal of Bone and foint Surgery, $47 \mathbf{B}, 137$.

Puschett, J. B., and Goldberg, M. (1968). Fournal of Laboratory and Clinical Medicine, 71, 666 .

Riedler, G. F., and Scheitlin, W. A. (1969). British Medical fournal, 1, 753

Saltzman, H. A., Heyman, A., and Sieker, H. O. (1963). New England Fournal of Medicine, 268, 143

Schumer, W., and Nyhus, L. M. (1970). Archives of Surgery, 100, 405.

Smith, D. A., and Nordin, B. E. C. (1964). Clinical Science, 26, 479.

Stein, J. H., Smith, W. O., and Ginn, H. E. (1966). American fournal of the Medical Sciences, $252,78$.

Thomas, Sucy, and Corden, Margaret. (1970). Tables of Composition of

Vianna, N. J. (1971). Fournal of the American Medical Association, 215, 1497.

\title{
Benzhexol and Side Effects with Long-acting Fluphenazine Therapy
}

\author{
LYNN GROVE, J. L. CRAMMER
}

\section{British Medical fournal, 1972, 1, 276-279}

\section{Summary}

Sixteen patients who had for some months been on fluphenazine enanthate injections $(1-3 \mathrm{ml})$ every two or three weeks, with daily oral benzhexol (6-40 mg), were divided into two groups comparable in age, diagnostic category, and drug dose.

Placebo was substituted under blind controlled conditions for benzhexol in one group, and both groups were regularly assessed by Simpson rating scale for extrapyramidal signs, and by a 30 -question symptom check list. Both assessments were found reliable.

Four out of eight patients had severe reactions when off

St. John's Hospital, Stone, Aylesbury, Bucks.

LYNN GROVE, M.B., B.S., Registrar

J. L. CRAMMER, M.R.C.S., L.R.C.P., D.P.M., Consultant (Present appointment: Senior Lecturer, Institute of Psychiatry, London) benzhexol, but symptoms such as tremor and daytime sleepiness were unaltered in all patients. The other four did not suffer adversely from withdrawal of benzhexol.

Acute withdrawal is therefore unjustified, but occasional revision of dosage of anti-Parkinsonian drugs is advisable. There is no evidence that tolerance develops to any effect of a phenothiazine, but long-continued benzhexol might induce a denervation supersensitivity. It is also possible that Parkinsonian signs are dependent on affective state.

\section{Introduction}

When the long-acting phenothiazine fluphenazine enanthate was first introduced for the treatment of psychosis by single intramuscular injections spaced weeks apart it was feared that the severity of the side effects commonly produced would make the drug unacceptable to patients. Kinross-Wright et al. (1963), in a trial in 147 patients, noted extrapyramidal reactions, chiefly of the episodic dystonic type, in over half of them, and 
complaints of dizziness, insomnia, dry mouth, and visual disturbance were common. However, it was found that antiParkinsonian drugs would allay these side effects, which were said to diminish in seriousness as fluphenazine treatment continued. Thus Millar and Daniel (1967) gave 33 patients who were adequately treated by $1 \mathrm{ml}(25 \mathrm{mg})$ of fluphenazine enanthate every two weeks a daily dose of benzhexol $12 \mathrm{mg}$ from the start for the first four months. In spite of this, half of them at first showed some extrapyramidal reaction, but later 22 were taken off benzhexol completely without ill effect and the other 11 were reduced to $6 \mathrm{mg}$ of benzhexol daily. Others (Stratas et al., 1963; St. Jean et al., 1964; Ananth et al., 1970) have also reported groups of patients under prolonged treatment with phenothiazines who suffered no ill effects when benzhexol, benztropine, or procyclidine was withdrawn. These observations are consistent with our own casual experience at follow-up clinics that some patients stop taking the anti-Parkinsonian drugs prescribed for them without suffering any distress.

It is obviously of practical importance if patients on long-term treatment with these phenothiazines do not need long-term benzhexol, benztropine, procyclidine, or orphenadrine which they are being given. This would invalidate some of the evidence which backs the manufacturer's claim that fluphenazine decanoate causes fewer side effects than the enanthate. But, in addition, it raises important questions fcr basic human pharmacology at two levels. (1) Can tolerance develop to any of the actions of phenothiazines and, if so, what is its mechanism? More generally, what are the body's responses to the chronic administration over long periods of drugs such as fluphenazine and benzhexol ? (2) What light is thrown on the physical causation of psychotic states by the appearance or disappearance of Parkinsonism and of signs of psychosis under the influence of different drugs?

We therefore decided to study the incidence of side effects in patients under chronic treatment with fluphenazine enanthate, and as part of our investigation to withdraw benzhexol under blind controlled conditions in a small group of 16 inpatients who were under close ward observation.

\section{Patients and Scheme of Trial}

Thirteen women and three men were selected as the only inpatients who were receiving regular fluphenazine enanthate injections every two or three weeks with regular daily benzhexol but no other anti-Parkinsonian drugs, other phenothiazines, or antidepressants. In most cases they had been under treatment for a long time (see Table I). They were free of organic disease

TABLE I-Details of the 16 Cases

\begin{tabular}{|c|c|c|c|c|c|c|c|}
\hline \multirow{2}{*}{$\begin{array}{l}\text { Case } \\
\text { No. }\end{array}$} & \multirow[t]{2}{*}{ Diagnosis* } & \multirow{2}{*}{\multicolumn{2}{|c|}{$\begin{array}{l}\text { Age } \\
\text { and } \\
\text { Sex }\end{array}$}} & \multicolumn{2}{|c|}{$\begin{array}{l}\text { Fluphenazine } \\
\text { enanthate }\end{array}$} & \multirow{2}{*}{$\begin{array}{l}\text { Benzhexol } \\
\text { (mg daily) }\end{array}$} & \multirow{2}{*}{$\underset{\text { Score }}{\text { Simpson }}$} \\
\hline & & & & Doset & Months & & \\
\hline \multicolumn{8}{|c|}{ Placebo Phase Group } \\
\hline $\begin{array}{l}1 \\
2 \\
3 \\
4 \\
5 \\
6 \\
7 \\
8\end{array}$ & $\begin{array}{l}\text { Cat. sch. } \\
\text { Cat. sch. } \\
\text { Aff. } \\
\text { Cat. sch. } \\
\text { Para. sch. } \\
\text { Cat. sch. } \\
\text { Para. sch. } \\
\text { Cat. sch. }\end{array}$ & $\begin{array}{l}26 \\
41 \\
43 \\
44 \\
56 \\
57 \\
56 \\
66\end{array}$ & $\begin{array}{l}\text { F. } \\
\text { F. } \\
\text { F. } \\
\text { F. } \\
\text { F. } \\
\text { M. } \\
\text { F. }\end{array}$ & $\begin{array}{l}50 / 2 \\
50 / 2 \\
50 / 2 \\
50 / 3 \\
37 / 2 \\
25 / 2 \\
25 / 3 \\
50 / 2\end{array}$ & $\begin{array}{r}8 \\
35 \\
22 \\
28 \\
5 \\
11 \\
24 \\
48\end{array}$ & $\begin{array}{r}15 \\
30 \\
15 \\
6 \\
22 \\
15 \\
6 \\
20\end{array}$ & $\begin{array}{r}6 \\
6 \\
0 \\
3 \\
11 \\
3 \\
0 \\
4\end{array}$ \\
\hline \multicolumn{7}{|c|}{ Simpson total } & 33 \\
\hline \multicolumn{8}{|c|}{ Continuous Benzhexol Group } \\
\hline $\begin{array}{r}99 \\
10 \\
11 \\
12 \\
13 \\
14 \\
15 \\
16\end{array}$ & $\begin{array}{l}\text { Cat. sch. } \\
\text { Cat. sch. } \\
\text { Aff. } \\
\text { Sch. } \\
\text { Sch. } \\
\text { Para. sch. } \\
\text { Para. sch. } \\
\text { Para. sch. }\end{array}$ & $\begin{array}{l}19 \\
43 \\
43 \\
45 \\
45 \\
50 \\
53 \\
63\end{array}$ & $\begin{array}{l}\text { F. } \\
\text { F. } \\
\text { F. } \\
\text { M. } \\
\text { F. } \\
\text { F. } \\
\text { M. } \\
\text { F. }\end{array}$ & $\begin{array}{l}50 / 2 \\
75 / 2 \\
37 / 2 \\
50 / 2 \\
50 / 3 \\
50 / 3 \\
75 / 2 \\
50 / 2\end{array}$ & $\begin{array}{r}3 \\
17 \\
51 \\
21 \\
6 \\
30 \\
2 \\
2\end{array}$ & $\begin{array}{l}15 \\
40 \\
30 \\
15 \\
30 \\
15 \\
15 \\
15\end{array}$ & $\begin{array}{r}3 \\
0 \\
8 \\
0 \\
17 \\
1 \\
6 \\
4\end{array}$ \\
\hline \multicolumn{7}{|c|}{ Simpson total } & 39 \\
\hline
\end{tabular}

*Cat. = catatonic; Sch. = schizophrenic; Para. = paranoid; Aff. = affective, possibly schizo-affective.

$+50 / 2=50 \mathrm{mg}$ every two weeks.
Cases $1,2,6$, and 7 (and later Cases 9 and 12) were affected by benzhexol withdrawal. and likely to remain in hospital for at least the period of our trial, and we are grateful to our colleagues for permitting them to be investigated.

An initial Simpson rating of extrapyramidal signs (see below) was made on each one so that the 16 could be secretly divided into two groups of eight which were roughly similar in age range, dose schedules, Simpson scores, and diagnostic categories. Unknown to staff and patients, one group was for a time switched to placebo tablets in place of benzhexol (placebo phase group), while the other continued on benzhexol throughout. Each individual was assessed and reassessed at the same time after every injection of long-acting fluphenazine.

Five patients in one group (placebo phase) and four in the other had been treated with chlorpromazine or trifluoperazine and put on benzhexol before they were started on fluphenazine injections. The other patients started on benzhexol because, according to their case records, while receiving injections they showed daytime sleepiness (Case 1) or sleepiness and tremor (Case 3) or stiffness and slowness (Cases 2, 10, 11, and 14) or visual disturbance and shaking (Case 16). Thus though all 16 had had drug side effects at some time, these might have resulted from a different dose of fluphenazine, or even from a different phenothiazine, from that which each patient was getting at the time of this trial. It must also be noted that sleepiness and tremor are not side effects particularly responsive to benzhexol. Diagnosis was decided by reading through the case papers, schizophrenia being accepted only if there was evidence of thought disorder and/or ideas of influence. Fourteen were certainly schizophrenic on this basis. Three patients in each group were so dilapidated, in spite of long previous residence in the community, as to require permanent hospital care. The others were in hospital for social reasons or to permit variation of medication. Onset of illness before 40 , with phases of excitement and withdrawal, led to a label of catatonic; onset after 40 , with persecutory auditory hallucinations, led to a label of paranoid.

\section{Assessments}

Each patient was assessed four or five days after each regular injection, and also just before the next injection in the series. The odd-numbered assessments were thus when side effects were maximal (Kinross-Wright et al., 1963) and the evennumbered assessments (made one or two weeks later than the odd numbers) when side effects were so minimal that they were dropped from further analysis. In the tables, therefore, all patients were receiving benzhexol when score I was made just after their injections, but half of them were on placebo when score III was made at the corresponding time after the following injection.

The assessments, each made separately without sight of the others, were (1) a physical examination with an 0-4 rating on each of the 10 items in Table III (Simpson and Angus, 1970), and (2) administration of a check list of 30 possible complaints compiled from experience of symptoms caused by drugs. Eighteen were admitted (see Table IV) by one or more of the group and scored 1 for mild and 2 for severe.

The continuous benzhexol group scored 39 (out of a theoretical maximum of 320) on the first and 37 on the third physical examination, and comparisons of group scores I and III for each physical sign (see Table III) shows good agreement, so that the rating was reliable. But individual patients were scored differently on the two occasions (see Table II).

Patients' spontaneous complaints of drug side effects often relate more to their expectations of the treatment or their lack of confidence in the doctor than to what they are experiencing and, like other clinical symptoms, may be influenced by suggestion. A repeatedly administered check list, even though it may put ideas into patients' heads (Glaser and Whittow, 1954), is a surer way of assessing the incidence of drug symptoms (see Belson and Duncan, 1962). Under constant circumstances a 
group's score falls on repeated administration of the same check list (Glaser, 1953, 1954), and Table IV shows a drop from 60 to 43 , with a measure of agreement on the individual symptoms. But again the individual patient achieved different scores at different assessments (or the same score by a different array of complaints). While these measures may be used on groups of patients, therefore, they are unsuitable for the assessment of individuals.

\section{Results}

It was expected that benzhexol withdrawal would result in only mild symptoms, but this was not so. Four patients developed severe reactions which left no doubt that benzhexol should be continued in them. Case 1 developed restlessness and Parkinsonism and at once put herself on her private store of benzhexol, hence score III in Tables II and V could only be called big. Case 2 on the day after injection developed diarrhoea, sweating, and malaise. Case 6 on the third day after injection began to feel jittery, and on the fourth showed pronounced akathisia and Parkinsonism, becoming mentally disturbed. Case 7 on the second day after injection became stiff, unable to speak or swallow properly, and got urinary retention, becoming mentally disturbed.

After the trial it was possible to withdraw benzhexol also from two members of the other group (Cases 9 and 12) and they also developed similar symptoms.

TABLE II-Total Simpson Ratings of Parkinsonism on the Two Occasions

\begin{tabular}{|c|c|c|c|c|c|c|c|}
\hline \multicolumn{4}{|c|}{ Placebo Phase Group } & \multicolumn{4}{|c|}{ Continuous Benzhexol Group } \\
\hline Case No. & & Score I & Score III & Case No. & & Score I & Score III \\
\hline $\begin{array}{ll}1 & \ldots \\
2 & \cdots \\
3 & \cdots \\
4 & \cdots \\
5 & \cdots \\
6 & \cdots \\
7 & \cdots \\
8 & \cdots\end{array}$ & $\begin{array}{l}. \\
\ldots \\
\cdots \\
\cdots \\
\cdots\end{array}$ & $\begin{array}{r}6 \\
6 \\
0 \\
3 \\
11 \\
3 \\
0 \\
4\end{array}$ & $\begin{array}{c}\text { (big) } \\
27 \\
2 \\
7 \\
1 \\
16 \\
20 \\
2\end{array}$ & $\begin{aligned} 9 & . \\
10 & . \\
11 & . \\
12 & \cdots \\
13 & \cdots \\
14 & \cdots \\
15 & \cdots \\
16 & \cdots\end{aligned}$ & $\begin{array}{l}\ldots \\
\cdots \\
\cdots \\
\because . \\
\cdots \\
\therefore\end{array}$ & $\begin{array}{r}3 \\
0 \\
8 \\
0 \\
17 \\
1 \\
6 \\
4\end{array}$ & $\begin{array}{r}4 \\
2 \\
1 \\
4 \\
4 \\
12 \\
4 \\
7 \\
3\end{array}$ \\
\hline Total & .. & 33 & 74 & Total & $\ldots$ & 39 & 37 \\
\hline
\end{tabular}

TABLE III-Group Total Score for Each Sign in Simpson Rating

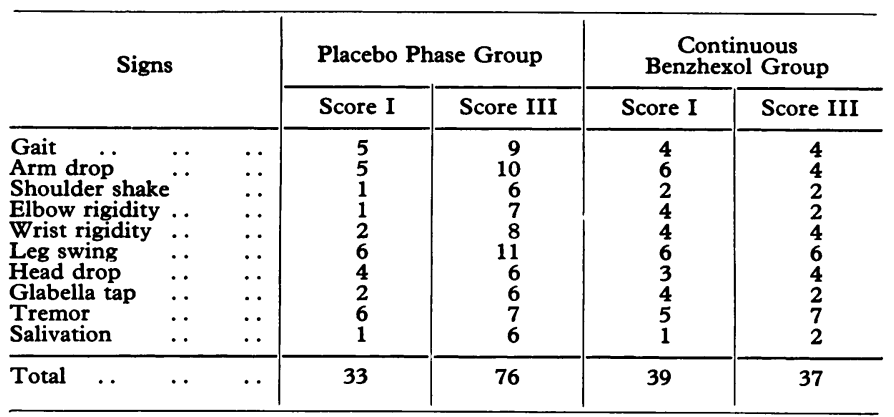

Table II shows that Parkinsonian signs remained steady in the group kept on constant benzhexol, but increased markedly in the placebo group as a whole. Yet this rise was due wholly to the scores of Cases 2, 6, and 7, while the scores of Cases 5 and 8 actually declined. Table III shows that head drop and especially tremor remained constant despite benzhexol withdrawal, whereas other signs increased.

The symptom check list (Table IV) showed an evenly spaced drop in score with repetition in the continuous benzhexol group (as expected-Glaser and Whittow, 1954), but a nearly threefold rise in the placebo group. This rise was in the first 11 symptoms only:

Change in score on first 11: placebo group +48 , benzhexol -5

$$
\text { " " " last 7:" " } " 2 \text {, " } 12
$$

Again, the rise was due to change in only four patients (Cases $1,2,6$, and 7) (Table V). These patients also complained
TABLE IV-Group Totals for Each of 18 Symptoms on the Two Occasions

\begin{tabular}{|c|c|c|c|c|c|}
\hline \multicolumn{2}{|l|}{ Symptoms } & \multicolumn{2}{|c|}{ Placebo Phase Group } & \multicolumn{2}{|c|}{$\begin{array}{c}\text { Continuous } \\
\text { Benzhexol Group }\end{array}$} \\
\hline & & Score 1 & Score III & Score I & Score III \\
\hline 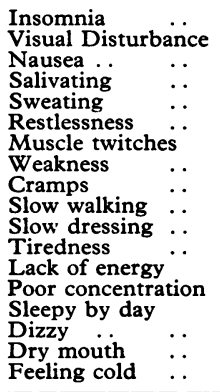 & $\begin{array}{l}\ldots \\
\cdots \\
\cdots \\
\cdots \\
\cdots \\
\cdots \\
\cdots \\
\cdots \\
\cdots \\
\cdots \\
\cdots \\
\cdots \\
\cdots\end{array}$ & $\begin{array}{l}0 \\
0 \\
0 \\
0 \\
2 \\
3 \\
1 \\
3 \\
3 \\
2 \\
0 \\
4 \\
3 \\
4 \\
2 \\
1 \\
1 \\
0\end{array}$ & $\begin{array}{l}8 \\
2 \\
2 \\
6 \\
7 \\
9 \\
7 \\
5 \\
5 \\
5 \\
6 \\
5 \\
5 \\
3 \\
3 \\
0 \\
1 \\
0\end{array}$ & $\begin{array}{l}1 \\
2 \\
3 \\
2 \\
1 \\
5 \\
2 \\
4 \\
4 \\
2 \\
0 \\
7 \\
7 \\
6 \\
7 \\
2 \\
3 \\
2\end{array}$ & $\begin{array}{l}0 \\
3 \\
0 \\
4 \\
3 \\
4 \\
2 \\
2 \\
2 \\
1 \\
0 \\
6 \\
5 \\
3 \\
7 \\
0 \\
0 \\
1\end{array}$ \\
\hline Total & $\ldots$ & 29 & 79 & 60 & 43 \\
\hline
\end{tabular}

individually of symptoms not in the check list-palpitations, hiccup, urinary retention, headache, small handwriting-so that the check list was not a precisely aligned measuring instrument. It is interesting that Cases $1,2,6$, and 9 were all catatonic schizophrenics (Table I).

TABLE v-Symptom Scores for Each Patient on the Two Occasions

\begin{tabular}{|c|c|c|c|c|c|c|c|c|c|}
\hline \multicolumn{5}{|c|}{ Placebo Phase Group } & \multicolumn{5}{|c|}{ Continuous Benzhexol Group } \\
\hline \multicolumn{3}{|c|}{ Case No. } & \multirow[b]{2}{*}{$\begin{array}{c}\text { Score I } \\
3 \\
1 \\
6 \\
6 \\
1 \\
1 \\
7 \\
4\end{array}$} & \multirow[b]{2}{*}{$\begin{array}{c}\text { Score III } \\
\text { (big) } \\
12 \\
9 \\
12 \\
0 \\
21 \\
15 \\
1\end{array}$} & \multicolumn{3}{|c|}{ Case No. } & \multirow[b]{2}{*}{$\begin{array}{c}\text { Score I } \\
7 \\
1 \\
4 \\
12 \\
14 \\
11 \\
3 \\
8\end{array}$} & \multirow[b]{2}{*}{$\begin{array}{c}\text { Score III } \\
11 \\
3 \\
1 \\
10 \\
6 \\
4 \\
3 \\
5\end{array}$} \\
\hline $\begin{array}{l}1 \\
2 \\
3 \\
4 \\
5 \\
6 \\
7 \\
8\end{array}$ & $\begin{array}{l}\ldots \\
\because \\
\because \\
\because \\
\because \\
\cdots\end{array}$ & $\begin{array}{l}\ldots \\
\because \\
\because \\
\because \\
\because \\
\therefore\end{array}$ & & & $\begin{array}{r}9 \\
10 \\
11 \\
12 \\
13 \\
14 \\
15 \\
16\end{array}$ & $\begin{array}{l}\ldots \\
\because \\
\because \\
\because \\
\because \\
\cdots \\
\cdots\end{array}$ & $\begin{array}{l}\ldots \\
\because \\
\because \\
\because \\
\ldots \\
\ldots\end{array}$ & & \\
\hline & Total & .. & 29 & 70 & & Cotal & .. & 60 & 43 \\
\hline
\end{tabular}

\section{Discussion}

Though the numbers are small, the results are clear enough. The benzhexol group suffered more severely than the placebo group initially when all were on benzhexol (as shown by various measures), but this only threw the effects of withdrawal into greater relief. The three women and one man who showed severe reactions on benzhexol withdrawal had been under treatment by long-acting injections for from 8 to 35 months and had been taking benzhexol at least for that time. Clearly they still required benzhexol, and equally the other four from whom it was withdrawn did not. These reactions occurred in two patients who were receiving $25 \mathrm{mg}$ of fluphenazine enanthate every two or every three weeks and in two who were receiving $50 \mathrm{mg}$ every two weeks, which was more the dose level of the group as a whole. Some patients, therefore, cannot stand withdrawal of anti-Parkinsonian drugs, and a general acute withdrawal of such drugs from outpatients would be most unwise. This is not to say, however, that periodic review of these drugs is unnecessary. A patient once put on benzhexol tends to stay on benzhexol even though the dose and nature of the phenothiazine may be changed from time to time in the direction of fewer side effects. Occasional cautious reduction in benzhexol dose, frequently monitored, may then be advisable.

Others have thought that anti-Parkinsonian drugs were unnecessary. Stratas et al. (1963) took these drugs away from 88 women inpatients receiving oral phenothiazines to the equivalent of $80-3,100 \mathrm{mg}$ of chlorpromazine daily. Three-quarters of them showed no akathisia, rigidity, tremor at rest, dystonia, drooling, or shuffling gait in the following nine weeks. One-quarter developed some Parkinsonism, treated simply by a reduction in phenothiazine dosage. 
St. Jean et al. (1964) suddenly withdrew the drugs from 17 inpatients on oral phenothiazines, and five of them developed Parkinsonism. Another group of 19 were suddenly put on placebo and none of them developed any akathisia, rigidity, etc. (as above). They argued that psychological treatment was sufficient to keep side effects at bay. Ananth et al. (1970) divided 80 chronic inpatients ( 33 were men) with a variety of diagnoses into a control group and a sudden withdrawal group, and of the latter 40 only four men got pronounced extrapyramidal symptoms.

Even inpatients may fail to take oral phenothiazines. Our study, though on small numbers, was on patients who were receiving fluphenazine with certainty; the assessments were wide and detailed and all carried out by one doctor instead of by the changing members of a team of nurses and doctors, and attention was paid both to each patient's previous drug history and to diagnosis. Half of our patients in each group had been started on benzhexol when still on some dose of an oral phenothiazine, long before the injection treatment. On the other hand, two of the placebo group who got severe Parkinsonian reactions had been started on benzhexol only when injections were producing side effects, albeit months before. The suggestion that tolerance develops to phenothiazine side effects requires as part of its proof a constancy of dosage of one phenothiazine and one anti-Parkinsonian drug over the relevant time, and this evidence is not available. Indeed there is at present equal validity for the opposite suggestion, the development of a hypersensitivity.

The severity of the withdrawal reactions was a surprise, and the patients had not previously experienced effects of this order. This may be because they had never hitherto been exposed unprotected to the full action of that dose of fluphenazine, but Calne (1970) remarked: "Patients with Parkinsonism of moderate severity obtain maximum benefit from anti-cholinergic agents. In such cases sudden withdrawal of treatment may precipitate a marked deterioration in clinical status which is often out of proportion to the therapeutic benefit which had previously been noted." This suggests that long chemical blockade may induce a kind of denervation supersensitivity in the central nervous system, and this requires further inquiry.

As regards the effectiveness of anticholinergic drugs, such as benzhexol, Calne stated that "in general rigidity responds best, tremor is less easy to help and hypokinesia seldom improves," and tremor was in fact unaffected by benzhexol in our patient group. It was not the only side effect of fluphenazine to be poorly controlled, daytime sleepiness being one and to some extent internal restlessness another. Our results show that fluphenazine produces other side effects than those controllable with benzhexol. We noted, however, that some schizophrenic patients are indifferent to all side effects, and will deny them even when they are visible to the examiner; others are constantly upset by them and feel really well only when the injections are stopped, in the weeks or months before psychotic symptoms reappear.

The fact that the onset of a depressive illness in an otherwise normal person may bring out Parkinsonian signs which vanish again as the depression clears is well known. Also it is well recognized that chronic deteriorated schizophrenics with loss of affect and drive and no florid symptoms are little improved by phenothiazines and often peculiarly resistant to any effects of the drug whatsoever, whereas some other schizophrenics seem peculiarly liable to develop extrapyramidal signs (Davison and Bagley, 1959). This leads on to the idea that the liability of an individual to develop manifest Parkinsonism in response to a drug such as fluphenazine may depend on the individual's affective state or state of arousal at the time (Kornetsky and Mirsky, 1966). This would then explain why some individuals do not need a drug like benzhexol while others need it intermittently in varying dose and yet others need it all the time. Of our patients who were unperturbed by benzhexol withdrawal, one probably had had an affective illness and two were apathetic anergic chronic schizophrenics. The matter could be further investigated by developing a pharmacological test briefly provocative of Parkinsonian symptoms according to size of test dose, for instance with physostigmine (Duvoisin, 1967), which could be applied to schizophrenics and others.

We are grateful to Cyanamid of Gt. Britain Limited for the gift of placebo tablets matched to Artane (benzhexol); to Mr. F. Smith, our pharmacist, for controlling the distribution of tablets according to the plan; and to the ward sisters who supervised the patients. Dr. F. Pinto carried out the preliminary preparations for the trial.

Requests for reprints should be sent to Dr. J. L. Crammer, Institute of Psychiatry, De Crespigny Park, London S.E.5.

\section{References}

Ananth, J. V., Horodesky, S., Lehmann, H. E., and Ban, T. A. (1970). Laval Médical, 41, 934.

Belson, W. A., and Duncan, J. A. (1962). Applied Statistics, 2, 120.

Calne, D. B. (1970). Parkinsonism: Physiology, Pharmacology, Treatment, p. 74. London, Ärnold.

Davison, K., and Bagley, C. R. (1969). British fournal of Psychiatry, Special Publication No. 4, p. 135.

Duvoisin, R. (1967). Archives of Neurology, 17, 124.

Glaser, E. M. (1953). British fournal of Pharmacology and Chemotherapy, 8, 187 .

Glaser, E. M. (1954). Clinical Science, 13, 475.
Glaser, E. M., and Whittow, G. C. (1954). Clinical Science, 13, 199.

Glaser, E. M., and Whittow, G. C. (1954). Clinical Science, 13, 199. fournal of Psychiatry, 119, 779 .

Kornetsky, C., and Mirsky, A. F., (1966). Psychopharmacologia, 8,

309. Simpson, G. M., and Angus, J. W. S. (1970). Acta Psychiatrica Scandinavica, Suppl. No., 212, p. 11 .

St. Jean, A., Donald, $M$. W., and Ban, T. A. (1964). American fournal of Psychiatry, 120,801.

Stratas, N. E., Philips, R. D., Walker, P. A., and Sandifer, M. G. (1963). Diseases of the Nervous System, 24, 180 . 